\title{
Synergistic antibacterial activity of monoterpenes in combination with conventional antimicrobials against Gram-positive and Gram-negative bacteria
}

\author{
Atividade antibacteriana sinérgica de monoterpenos combinados com \\ antimicrobianos convencionais frente a bactérias Gram-positivas e Gram-negativas
}

Maria Helena Pereira de Lira ${ }^{1}$, Gustavo Fernandes Queiroga Moraes ${ }^{2}$, Girlene Macena Santos ${ }^{2}$, Francisco Patrício de Andrade Júnior ${ }^{3}$, Fillipe de Oliveira Pereira ${ }^{4}$, Igara de Oliveira Lima ${ }^{5}$

\begin{abstract}
${ }^{1}$ Mestra em Ciências Naturais e Biotecnologia, Laboratório de Microbiologia - CES/UFCG; ${ }^{2}$ Estudante de Farmácia, Laboratório de Microbiologia - CES/UFCG; ${ }^{3}$ Mestrando em Produtos Naturais e Sintéticos Bioativos, Laboratório de Microbiologia - CCS/UFPB; ${ }^{4}$ Doutor em Produtos Naturais e Sintéticos Bioativos, Laboratório de Bioquímica-CES/UFCG; ${ }^{5}$ Doutora em Produtos Naturais e Sintéticos Bioativos, Laboratório de Microbiologia-CES/UFCG.
\end{abstract}

\begin{abstract}
Introduction: bacterial infections are a public health problem. Besides, the emergence of strains resistant to antimicrobials has contributed to the search for new alternatives, such for the terpenes with antimicrobial potential. Objectives: the objective of this study was to determine the possible interaction of isolated monoterpenes (-)-Carveol, Geraniol, Citronellol, $\alpha$-terpineol, $R$-(-) Carvone, (-)-Menthol, Linalool, D-Dihydrocarvone, and (-)-Terpine-4-ol with conventional antimicrobials (Chloramphenicol, Minocycline, Amoxicillin and Ciprofloxacin) when they are evaluated on Staphylococcus aureus, Staphylococcus epidermidis, Bacillus subtilis, Escherichia coli and Pseudomonas aeruginosa strains. Methodology: the minimum inhibitory concentrations of these test drugs were determined using the microdilution method. The Checkerboard method was used to assess the interactions, by determining the fractional inhibitory concentration index (FIC index). Results: aamong the monoterpenes, only Carveol, Citronellol, and Geraniol presented antimicrobial activity (MIC $<1024 \mu \mathrm{g} / \mathrm{mL}$ ). They presented synergistic effects against Pseudomonas aeruginosa ATCC-9027 (FIC index $\leq 0.5$ ) when in combination with Minocycline. Conclusion: this study contributes to the development of new approaches to control bacterial resistance and to the possibility of discovering new drugs.
\end{abstract}

Keywords: Monoterpenes. Antimicrobials. Complementary Therapies.

\begin{abstract}
Resumo
Introdução: as infecções bacterianas são um problema de saúde pública. Além disso, o surgimento de cepas resistentes aos antimicrobianos tem contribuído para a busca de novas alternativas, como a pesquisa de terpenos com potencial antimicrobiano. Objetivos: o objetivo deste estudo foi determinar a possível interação de monoterpenos isolados (-) - Carveol, Geraniol, Citronelol, $\alpha$-terpineol, R - (-) Carvona, (-)-Mentol, Linalol, D-Diidrocarvona e (-)-Terpina-4-ol com antimicrobianos convencionais (cloranfenicol, minociclina, amoxicilina e ciprofloxacina) quando avaliados em Staphylococcus aureus, Staphylococcus epidermidis, Bacillus subtilis, Escherichia coli e Pseudomonas aeruginosa. Metodologia: as concentrações inibitórias mínimas destas drogas foram determinadas usando o método de microdiluição. O método checkerboard foi utilizado para avaliar as interações, determinando o índice de concentração inibitória fracionária (índice FIC). Resultados: entre os monoterpenos, apenas Carveol, Citronelol e Geraniol apresentaram atividade antimicrobiana ( $\mathrm{CIM}<1024 \mu \mathrm{g} / \mathrm{mL}$ ). Eles apresentaram efeitos sinérgicos contra Pseudomonas aeruginosa ATCC-9027 (índice FIC $\leq 0,5)$ quando em combinação com Minociclina. Conclusão: este estudo contribui para o desenvolvimento de novas abordagens para o controle da resistência bacteriana e para a possibilidade de descoberta de novas drogas.

Palavras-chave: Monoterpenos. Antimicrobianos. Terapias complementares.
\end{abstract}

\section{INTRODUCTION}

In global health care, bacterial infections continue to be important. They can cause both superficial and deep tissue damage, and classic microorganisms now considered to be opportunistic pathogens have become a

Correspondente/Corresponding: *Fillipe de Oliveira Pereira End:Centro de Educação e Saúde, Universidade Federal de Campina Grande - Campus CUité. Olho D'água da Bica S/N. Cuité, PB, Brasil. CEP: 58175-000 - E-mail: fillipeopereira@ufcg.edu.br - Tel: +55 (83) 3372-1826 / 3372-1900 recurrent concern. Examples of such diseases are impetigo, infectious endocarditis, abscesses, and sepsis as caused by Staphylococcus aureus considered the most important Gram-positive species ${ }^{1}$. Within the genus Staphylococcus, it is worth mentioning S. epidermidis, a principal negative coagulase human skin commensal, which causes nosocomial infections in patients undergoing invasive procedures ${ }^{2}$. Escherichia coli, (a Gram-negative bacillus), is a pathogen of clinical relevance due to affecting the gastrointestinal tract as well causing urinary tract infections, infectious endocarditis, osteomyelitis and sepsis ${ }^{3}$. Pseu- 
domonas aeruginosa, another Gram-negative bacillus is related to systemic and hospital-environment infections, such as pneumonia ${ }^{4}$. Bacillus subtilis, a Gram-positive bacillus, is notably involved in infections in hospitalized patients ${ }^{5}$.

The emergence and increase of antimicrobial-resistant strains represents negative impacts for morbidity, mortality, and economics worldwide ${ }^{6}$. Antibiotic resistance is codified in various genes; many of which can be transferred between bacteria. Resistance mechanisms may vary by bacterial species, strain, and antimicrobial agent, yet the phenomenon of resistance often involves more than a single group of drugs. Resistance occurs when reducing the intracellular concentration of the drug, through alterations or protection of the target site, or by direct antibiotic inactivation ?

The increases observed in microbial resistance involve intrinsic bacterial genetic factors, yet can also be attributed to factors such as overly liberal prescription writing, inappropriate antibiotic sale, and the wide use of antibiotics outside of the healthcare sector. Antimicrobial resistance presents significant challenges for clinical therapy. Yet modified use of antimicrobial agents, associated with new antimicrobial strategies may help overcome the difficulties of coping with resistant organisms in the future ${ }^{8}$.

Natural products have shown to be important tools in the search for new antimicrobial drugs, and can modulate microorganism sensitivity to conventional antibiotic drugs $(C A D)^{9}$. Essential oils are complex low molecular weight compound mixtures which are extracted from various plant parts; as their principal constituents they present monoterpenes ${ }^{10}$. The potential of essential oils and their phytoconstituents to serve as antibacterial and antifungal agents is well recorded in the literature. The chief mechanisms involved in the antimicrobial activity of these natural products are disruption of membrane integrity and increased permeability; this disturbs many cellular activities, including energy production and metabolic regulatory functions ${ }^{11}$.

In this study, (-)-Carveol, Geraniol, Citronellol, $\alpha$-terpineol, R-(-) Carvone, (-)-Menthol, Linalool, D-Dihydrocarvone, and (-)-Terpine-4-ol were investigated for antimicrobial activity both when isolated and when combined with CADs (Chloramphenicol, Minocycline, Amoxicillin, and Ciprofloxacin) against strains of Gram-positive and negative bacteria.

\section{METHODOLOGY}

\section{Tested drugs}

The monoterpene drugs (-)-Carveol, R-(-)-Carvona, D-Dihydrocarvone, Geraniol, Citronellol, Linalool, $\alpha$-terpineol, (-)-Menthol, (-)-terpine-4-ol and the CAD Ciprofloxacin Amoxicillin, Chloramphenicol and Minocycline were acquired from Sigma Aldrich ${ }^{\circledR}$ (Brazil). For solubilization of the monoterpenoids in water, Tween 80 (Sigma-Aldrich ${ }^{\circledR}$,
Brazil) was used up to the maximum concentration of $1 \%$. The solutions were prepared for each phytoconstituent to obtain an initial concentration of $1024 \mathrm{\mu g} / \mathrm{mL}$.

\section{Bacterial strains}

The bacterial strains used were Staphylococcus aureus ATCC-25923, Staphylococcus aureus ATCC-6538, Staphylococcus epidermidis ATCC-12228, Bacillus subtilis ATCC6633, Escherichia coli L1105, Pseudomonas aeruginosa ATCC 9027, and Pseudomonas aeruginosa ATCC-27853. During the experiments all strains were kept in test tubes containing Muller Hinton agar (DIFCO ${ }^{\circledR}$ ) and stored under refrigeration at $4^{\circ} \mathrm{C}$.

\section{Inoculum}

Inoculum preparations were performed from recent cultures of each strain previously cultivated in sterile tubes (containing Muller Hinton agar) and incubated at $35^{\circ} \mathrm{C}$ for 24 hours to achieve satisfactory growth. The bacterial colonies were then suspended in $10 \mathrm{~mL}$ of sterile saline solution (0.9\%). The resultant suspension was stirred under vortex and adjusted according to turbidity tube number 0.5 of the McFarland scale, which corresponds to $1-2 \times 10^{8} \mathrm{CFU} / \mathrm{mL}^{12}$.

\section{Determination of the Minimum Inhibitory Concentrations (MIC)}

Determination of the MICs of the test drugs (monoterpenes and $C A D$ ) was performed using the microdilution technique in microtitulation plates containing 96 wells, and a " $\mathrm{U}$ " bottom. To each plate well, $100 \mu \mathrm{L}$ of double concentrated BHI (brain heart infusion - DIFCO ${ }^{\circledR}$ ) liquid medium was added. Subsequently, $100 \mu \mathrm{L}$ of the monoterpenoid solution was dispensed in the first line of the plate wells. Through serial dilution at a ratio of 2, concentrations of 1024 to $1 \mu \mathrm{g} / \mathrm{mL}$ were obtained for columns 1 to 11 . Finally, $10 \mu \mathrm{L}$ of test strain inoculum was added to each well. The last column was reserved for the microorganism growth control (BHI broth, without test product). Both growth controls (broth without drugs) and sterility controls (broth without inoculum) ${ }^{12}$ were performed. The assay was performed in triplicate and submitted to incubation at 370 $\mathrm{C}$ for 24 hours. After incubation, $20 \mu \mathrm{L}$ of the indicator solution (1\% resazurin) was added to each well. A change from blue to pink indicates bacterial growth, providing MIC visualization; defined as the lowest concentration capable of inhibiting microbial growth.

\section{Antimicrobial Interaction Test}

Evaluation of the effects of the antimicrobial-terpenoid combinations on the tested strains was performed using the Checkerboard method. The test was performed on a microdilution plate with 96 wells. It was added $100 \mu \mathrm{L}$ of BHI to the plate wells. Subsequently $50 \mu \mathrm{L}$ of monoterpene was distributed vertically in the following 
concentrations (1/8MIC, 1/4MIC, 1/2MIC, MIC, 2MIC, $4 M I C$, or $8 M I C)$. Then $50 \mu \mathrm{L}$ of CAD was distributed in concentrations of (1/8MIC, 1/4MIC, $1 / 2 \mathrm{MIC}, M I C, 2 \mathrm{MIC}$, $4 \mathrm{MIC}$, or $8 \mathrm{MIC}$ ) so that the drugs could mix. Finally, $20 \mu \mathrm{L}$ of test strain inoculum was added. The plate was then transferred to an incubator, where it remained at $37^{\circ} \mathrm{C}$ for a period of 24 hours ${ }^{13}$. In the context of evaluating the activity of the drug associations, the fractional inhibitory concentration index (FICl) was calculated as the sum of: $F I C A+F I C B$, where A represents terpenes; and $B$ represents antimicrobial. Thus, FICA $=$ (MIC-A combined $) /($ MIC $-A$ alone), while FICB = (MIC-B combined $) /($ MIC-B alone $)$. The $\mathrm{FICl}$ was interpreted as: Synergism (<0.5), Additivity (0.51.0), Indifference (>1.0 and <4.0), or Antagonism (>4.0) ${ }^{14}$.

\section{RESULTS}

The monoterpenes with antibacterial effectiveness were (-)-Carveol, Citronellol, and Geraniol. The bacterial strain sensitivity results facing the monoterpenoids are shown in Table 1. (-) -Carveol presented an MIC of 512 $\mu \mathrm{g} / \mathrm{mL}$, indicating antibacterial activity against Pseudomonas aeruginosa ATCC-9027. Geraniol presented activity against S. epidermidis ATCC-12228, Pseudomonas aeruginosa ATCC-9027, and E. coli L1105, with MICS of 512 $\mu \mathrm{g} / \mathrm{mL}$. Citronellol presented activity against strains of $S$. epidermidis ATCC-12228 and Pseudomonas aeruginosa ATCC 9027, with respective MICs of $1024 \mu \mathrm{g} / \mathrm{mL}$ and 512 $\mu \mathrm{g} / \mathrm{mL}$. The other monoterpenes presented MICs above $1024 \mu \mathrm{g} / \mathrm{mL}$, thus presenting no antibacterial activity against the tested strains (Table 1).

According to the Clinical \& Laboratory Standards Institute $(C L S I){ }^{12}$, all of the studied strains are resistant to Chloramphenicol, except for P. aeruginosa ATCC 9027 $(\mathrm{MIC}=1 \mu \mathrm{g} / \mathrm{mL})$ and E. coli L1105 (MIC $=16 \mu \mathrm{g} / \mathrm{mL})$ which are sensitive (Table 2). P. aeruginosa ATCC 9027, E. coli L1105 and S. epidermidis ATCC 12228 were sensitive to Minocycline; the other microorganisms studied were considered resistant (MIC $>1024 \mu \mathrm{g} / \mathrm{mL}$ ). S. epidermidis ATCC 12228 was sensitive to Amoxicillin with an MIC of $0.25 \mu \mathrm{g} /$ $\mathrm{mL}$, and of the bacteria studied, only S. epidermidis ATCC $12228(\mathrm{MIC}=0.0625 \mu \mathrm{g} / \mathrm{mL}$ ) and $P$. aeruginosa ATCC 9027 $(M I C=0.25 \mu \mathrm{g} / \mathrm{mL}$ ) were sensitive to Ciprofloxacin. Practically all of the strains tested were resistant to Amoxicillin (MIC > $1024 \mu \mathrm{g} / \mathrm{mL}$ ).

The results of the association study involving Pseudomonas aeruginosa ATCC-9027 are shown in table 3. Pharmacological synergism was evidenced in the Geraniol-Minocycline, Carveol-Minocycline, and Citronellol-Minocycline associations. Pharmacological indifference was observed in the Geraniol-Ciprofloxacin, Geraniol-chloramphenicol, Citronellol-Chloramphenicol, and Citronellol-Ciprofloxacin associations against Pseudomonas aeruginosa ATCC 9027. With E. coli L1105 (Table 4), we found that combinations of Geraniol-Chloramphenicol and Geraniol-Minocycline were indifferent as for S. Epidermidis ATCC 12228, and indifference was also observed for the Citronellol-Minocycline and Citronellol-Ciprofloxacin associations. Antagonism was observed involving Pseudomonas aeruginosa ATCC 9027 (Table 3) in Carveol-Chloramphenicol and Carveol-Ciprofloxacin associations, and also for S. Epidermidis ATCC 12228 (Table 5) involving Citronellol-Amoxicillin, Geraniol-Minocycline, Geraniol-Ciprofloxacin, and Geraniol-Amoxicillin associations.

Table 1 - MIC values ( $\mu \mathrm{g} / \mathrm{mL}$ ) of terpenes against Gram-positive and Gram-negative bacteria.

\begin{tabular}{|c|c|c|c|c|c|c|c|c|c|}
\hline \multirow{2}{*}{ Strains } & \multicolumn{9}{|c|}{ Drugs } \\
\hline & (-) Carveol & Geraniol & Citronellol & $\alpha$-Terpineol & R-(-)Carvone & (-)-Mentol & Linalool & D-dihydrocarvone & (-)-Terpine-4-ol \\
\hline $\begin{array}{l}\text { Staphylococcus aureus } \\
\text { ATCC } 25923\end{array}$ & $>1024$ & $>1024$ & $>1024$ & $>1024$ & $>1024$ & $>1024$ & $>1024$ & $>1024$ & $>1024$ \\
\hline $\begin{array}{l}\text { Staphylococcus aureus } \\
\text { ATCC } 6538\end{array}$ & $>1024$ & $>1024$ & $>1024$ & $>1024$ & $>1024$ & $>1024$ & $>1024$ & $>1024$ & $>1024$ \\
\hline $\begin{array}{l}\text { Staphylococcus epidermi- } \\
\text { dis ATCC } 12228\end{array}$ & $>1024$ & 512 & 1024 & $>1024$ & $>1024$ & $>1024$ & $>1024$ & $>1024$ & $>1024$ \\
\hline $\begin{array}{l}\text { Bacillus subtilis } \\
\text { ATCC } 6633\end{array}$ & $>1024$ & $>1024$ & $>1024$ & $>1024$ & $>1024$ & $>1024$ & $>1024$ & $>1024$ & $>1024$ \\
\hline $\begin{array}{l}\text { Escherichia coli } \\
\text { L1105 }\end{array}$ & $>1024$ & 512 & $>1024$ & $>1024$ & $>1024$ & $>1024$ & $>1024$ & $>1024$ & $>1024$ \\
\hline $\begin{array}{l}\text { Pseudomonas aeruginosa } \\
\text { ATCC } 9027\end{array}$ & 512 & 512 & 512 & $>1024$ & $>1024$ & $>1024$ & $>1024$ & $>1024$ & $>1024$ \\
\hline $\begin{array}{l}\text { Pseudomonas aeruginosa } \\
\text { ATCC } 27583\end{array}$ & $>1024$ & $>1024$ & $>1024$ & $>1024$ & $>1024$ & $>1024$ & $>1024$ & $>1024$ & $>1024$ \\
\hline
\end{tabular}

*>1024: Drug was considered inactive.

Source: Research data. 
Table 2 - MIC values $(\mu \mathrm{g} / \mathrm{mL}$ ) of conventional antimicrobials against Gram-positive and Gram-negative bacteria.

\begin{tabular}{|c|c|c|c|c|}
\hline \multirow{2}{*}{ Strains } & \multicolumn{4}{|c|}{ Drugs } \\
\hline & Chloramphenicol & Minocycline & Amoxicillin & Ciprofloxacin \\
\hline $\begin{array}{l}\text { Staphylococcus aureus } \\
\text { ATCC } 25923\end{array}$ & $>1024$ & $>1024$ & $>1024$ & $>1024$ \\
\hline $\begin{array}{l}\text { Staphylococcus aureus } \\
\text { ATCC } 6538\end{array}$ & $>1024$ & $>1024$ & $>1024$ & $>1024$ \\
\hline $\begin{array}{l}\text { Staphylococcus epidermidis } \\
\text { ATCC } 12228\end{array}$ & $>1024$ & 0.25 & 0.25 & 0.0625 \\
\hline $\begin{array}{l}\text { Bacillus subtilis } \\
\text { ATCC } 6633\end{array}$ & $>1024$ & $>1024$ & $>1024$ & $>1024$ \\
\hline $\begin{array}{l}\text { Escherichia coli } \\
\text { L1105 }\end{array}$ & 16 & 0.5 & $>1024$ & $>1024$ \\
\hline $\begin{array}{l}\text { Pseudomonas aeruginosa } \\
\text { ATCC } 9027\end{array}$ & 1 & 2 & $>1024$ & 0.25 \\
\hline $\begin{array}{l}\text { Pseudomonas aeruginosa } \\
\text { ATCC } 27583\end{array}$ & $>1024$ & $>1024$ & $>1024$ & $>1024$ \\
\hline
\end{tabular}

*>1024: Drug was considered inactive.

Source: Research data.

Table 3 - MIC values $(\mu \mathrm{g} / \mathrm{mL})$ of antimicrobial drugs and the effect of combinations with terpenes against Pseudomonas aeruginosa ATCC 9027.

\begin{tabular}{|c|c|c|c|}
\hline & Drugs & MIC & FIC index (Type of interaction) \\
\hline \multirow{6}{*}{ MIC alone } & Geraniol & 512 & - \\
\hline & Carveol & 512 & - \\
\hline & Citronellol & 512 & - \\
\hline & Ciprofloxacin & 0.25 & - \\
\hline & Chloramphenicol & 1 & - \\
\hline & Minocycline & 2 & - \\
\hline \multirow{9}{*}{ Combined MIC } & Geraniol/Ciprofloxacin & $1024 / 0.03125$ & 2.125 (indifferent) \\
\hline & Geraniol/Chloramphenicol & $512 / 0.125$ & 1.125 (indifferent) \\
\hline & Geraniol/Mynocycline & $64 / 0.25$ & 0.25 (synergism) \\
\hline & Carveol/Ciprofloxacin & $2048 / 0.125$ & 4.5 (antagonism) \\
\hline & Carveol/Chloramphenicol & $4096 / 8$ & 16 (antagonism) \\
\hline & Carveol/Mynocycline & $64 / 0.5$ & 0.375 (synergism) \\
\hline & Citronellol/Ciprofloxacin & $1024 / 0.03125$ & 2.125 (indifferent) \\
\hline & Citronellol/Chloramphenicol & $1024 / 0.125$ & 1.125 (indifferent) \\
\hline & Citronellol/Mynocycline & $64 / 0.25$ & 0.25 (synergism) \\
\hline
\end{tabular}

*MIC, minimal inhibitory concentration; FIC, fractional inhibitory concentration.

Source: Research data.

Table 4 - MIC values $(\mu \mathrm{g} / \mathrm{mL})$ of antimicrobial drugs and the effect of combinations with terpenes against Escherichia coli L1105.

\begin{tabular}{clrc}
\hline \multicolumn{1}{c}{ Drugs } & & MIC & FIC index (Type of interaction) \\
\hline \multirow{3}{*}{ MIC alone } & Geraniol & 512 & \\
& Chloramphenicol & 16 & \\
& Mynocycline & 0.5 & \\
\hline \multirow{2}{*}{ Combined MIC } & Geraniol/Chloramphenicol & $512 / 2$ & 1.125 (indifferent) \\
& Geraniol/Mynocycline & $1024 / 0.0625$ & 2.125 (indifferent) \\
\hline
\end{tabular}

*MIC, minimal inhibitory concentration; FIC, fractional inhibitory concentration.

Source: Research data. 
Table 5-MIC values $(\mu \mathrm{g} / \mathrm{mL})$ of antimicrobial drugs and the effect of combinations with terpenes against Staphylococcus epidermidis ATCC 12228.

\begin{tabular}{llrr}
\hline \multicolumn{1}{c}{ Drugs } & & MIC & FIC index (Type of interaction) \\
\hline \multirow{3}{*}{ MIC alone } & Geraniol & 512 & \\
& Citronellol & 1024 & \\
& Ciprofloxacin & 0.0625 & \\
& Amoxicilin & 0.25 & \\
& Mynocycline & 0.25 & 4.125 (antagonism) \\
\cline { 2 - 3 } Combined MIC & Geraniol/Ciprofloxacin & 4.125 (antagonism) \\
& Geraniol/Amoxicillin & $2048 / 0.00781$ & 1.125 (indifferent) \\
\cline { 2 - 4 } & Geraniol/Mynocycline & $2048 / 0.03125$ & 16 (antagonism) \\
& Citronellol/Ciprofloxacin & $2048 / 0.03125$ & 2.125 (indifferent) \\
\hline
\end{tabular}

*MIC, minimal inhibitory concentration; FIC, fractional inhibitory concentration.

Source: Research data.

\section{DISCUSSION}

The antimicrobial activity of monoterpenes of this work has been reported in the scientific literature against several bacteria strains. Corroborating the results of our research on Carveol, a study conducted by Riahi et al. ${ }^{15}$ reported the antimicrobial activity of Mentha rotundifolia L essential oil against S. aureus, Bacillus Cereus, E. coli, Salmonella Typhimurium, and Aspergillus niger (Carveol being one of its main components). Ilić et al. ${ }^{16}$, has verified Geraniol as the principal compound in Thymus glabrescens essential oil; presenting antibacterial activity against $E$. coli ATCC-25922, Klebsiella pneumoniae ATCC-700603, Proteus mirabilis ATCC-12453, P. aeruginosa ATCC-27853, and S. aureus ATCC-29213. Kannappan et al. ${ }^{17}$ reported the inhibitory efficacy of Geraniol against formation of S. epidermidis RP62A associated biofilm. In a study evaluating the chemical and antimicrobial composition of Eucalyptus citriodora oil extract, Koudoro et al. ${ }^{18}$ found that Citronellol, among its principal compounds, presented activity against Candida albicans ATCC-10231 (MIC 0.63 $\mu \mathrm{L} / \mathrm{mL}$ ), E. coli ATCC-25922 (MIC $1.25 \mu \mathrm{L} / \mathrm{mL}$ ) and S. aureus ATCC-25923 (MIC $1.25 \mu \mathrm{L} / \mathrm{mL}$ ). Tsai et al. ${ }^{19}$ also found that Citronellol was the main constituent of Citrus grandis oil extract; presenting antimicrobial activity against $S$. aureus ATCC-6538, E. coli ATCC-25922, P. aeruginosa ATCC-9027 and C. albicans ATCC-10231.

In the scientific literature, the presence of bacteria resistant to CADs is well reported. In a study by Boss, Overesch e Baumgartner ${ }^{20}$, MIC values ranged from 8 to $128 \mu \mathrm{g} / \mathrm{mL}$, though bacterial strains of Escherichia coli, Enterococci, P. aeruginosa, and S. aureus presented as resistant to Chloramphenicol. In this study, the strains $E$. coli L1105 and P. aeruginosa ATCC-9027 were considered highly sensitive to Minocycline. This result diverges from that found by Taha e Eldahshan ${ }^{21}$ against E. coli MIC $=64$ $\mu \mathrm{g} / \mathrm{mL}$. However, the other strains tested were resistant to Minocycline. Both strains of $S$. aureus presented an
MIC value of $1024 \mu \mathrm{g} / \mathrm{mL}$, diverging from results found in studies by Ahmed et al. ${ }^{22}$ which obtained MIC values ranging from 7.81 to $62.5 \mu \mathrm{g} / \mathrm{mL}$. Here found E. coli L1105 and $B$. subtilis to be resistant (MIC $>1024 \mu \mathrm{g} / \mathrm{mL}$ ) as opposed to the results obtained by Ali et al. ${ }^{23}$ who found MIC values of $8 \mu \mathrm{g} / \mathrm{mL}$.

Amoxicillin is one of the most commonly prescribed antibiotics used to treat bacterial infections. Although resistance to Amoxicillin is not yet considered a serious clinical concern, the phenomenon cannot be neglected ${ }^{24}$. Regarding Ciprofloxacin, CLSI ${ }^{12}$ informs that for bacteria belonging to the Enterobacteriaceae family, an MIC of $\geq$ $16 \mu \mathrm{g} / \mathrm{mL}$ indicates microorganism resistance. In the case of $P$. aeruginosa and microorganisms not belonging to the Enterobacteriaceae family, MIC values $\leq 1 \mu \mathrm{g} / \mathrm{mL}$ indicate that the microorganism is sensitive. An MIC of between 1 and $4 \mu \mathrm{g} / \mathrm{mL}$ indicates intermediate sensitivity; and an MIC of $\geq 4 \mu \mathrm{g} / \mathrm{mL}$ is indicative of bacterial resistance. Thus, we observed that of the bacteria studied, only S. Epidermidis ATCC $12228(\mathrm{MIC}=0.0625 \mu \mathrm{g} / \mathrm{mL})$ and $P$. aeruginosa ATCC 9027 (MIC $=0.25 \mu \mathrm{g} / \mathrm{mL}$ ) were sensitive to Ciprofloxacin.

Due to increased bacterial resistance and the poor availability of new antibiotics, new strategies need to be evaluated. It is in this context, that natural products associated with CADs can be used to modulate bacterial sensitivity. For various microorganisms, drug combinations using essential oils and their constituents have been reported for presenting synergistic and additive effects, and even for inhibiting drug activity in antimicrobial interactions ${ }^{25}$.

In this study, associations between the monoterpenes Carveol, Geraniol and Citronellol and the CAD Ciprofloxacin, Chloramphenicol, Amoxicillin, and Minocycline were investigated against Pseudomonas aeruginosa ATCC-9027, Escherichia coli L1105 and Staphylococcus epidermidis ATCC-12228.

Few reports have been found in the literature demonstrating the effects of associations between the natural 
drugs used in this study with CAD. A study by llic et al. ${ }^{16}$ reported an association of Geraniol and Chloramphenicol presenting synergism against strains of E. coli ATCC25922, K. pneumoniae ATCC-700603, Proteus mirabilis ATCC-12453, and P. aeruginosa ATCC-27853. Other studies addressing the use of Carveol in the checkerboard method were not found in the literature. In a study by Rosato et al. ${ }^{26}$ associating Citronellol and Norfloxacin, synergism against strains of $B$. cereus and $S$. aureus was observed; this result diverges from those found in our research where Ciprofloxacin, a drug of the same class as Norfloxacin (Quinolones), was indifferent for the microorganisms studied.

Antimicrobial synergy offers alternative treatment options for treating pathogens resistant to all other available or acceptable therapies. The phenomenon in which two agents combined exert greater activity together than individually makes it possible that the dosages of some of the most toxic antibiotics can be reduced, greatly attenuating risks ${ }^{27}$. Although certain combinations present as indifferent, they have the advantage of not being antagonistic and the combination can be justified for being able to reduce the drug dosage, and reduce or delay antimicrobial resistance to treatment, thus potentializing the activity of the drug by acting on the same mechanism to increase the spectrum of action ${ }^{28}$.

On the other hand, antagonism observed in the combination results may indicate that the presence of the terpene together with the antibiotic interferes in the biological effect, possibly precluding its use in therapy. Antagonism however, can still serve as a pharmacological tool that enables deeper investigations in the face of possible drug poisonings, since an antagonistic combination can reduce activity. The molecular mechanisms involved in synergies between natural products and CADs are not fully delineated. But it is seen that for natural products, performance in different cellular targets relies on the sum of various mechanisms of action, or on inhibition of efflux pump activity ${ }^{8,25}$.

\section{CONCLUSIONS}

The results of this work show that the synergistic effects observed when combining monoterpenes with CAD are promising especially because it involves antibacterial resistant bacteria. The synergistic associations presented here serve as an incentive for the scientific community and shed more light on a new approach to controlling bacterial resistance and discovering new drugs. However, in vitro studies are essential to continue research focused on clinical use.

\section{ACKNOWLEDGEMENTS}

The authors thank the Dr. Edeltrudes de Oliveira Lima of the Mycology laboratory at the Department of Pharmaceutical Sciences, Federal University of Paraiba for the supply of strains.

\section{REFERENCES}

POLLITT, E. J.G. et al. Staphylococcus aureus infection dynamics. PLOS Pathog., Notre Dame, v.14, n.6, p. 1-27, 2018.

MÉRIC, G. et al. Disease-associated genotypes of the commensal skin bacterium Staphylococcus epidermidis. Nat. Commun., London, v.9, n.5034, p.1-11, 2018.

VILA, J. et al. Eschericha coli: na old friend with new tidings. FEMS Microbiol. Rev., Oxford, v.40, n.4, p.437-463, 2016.

BRADSHAW, J. L. et al. Pseudomonas aeruginosa Protease IV Exacerbates Pneumococcal Pneumonia and Systemic Disease. Msphere, Michigan, v.3, n.3, p.1-10, 2018.

CELANDRONI, F. et al. Identification and Pathogenic Potential of Clinical Bacillus and Paenibacillus Isolates. PLos ONE, California, v.11, n.3, e0152831, 2016.

TACCONELLI, E. et al. Discovery, research, and development of new antibiotics: the WHO priority list of antibiotic-resistant bacteria and tuberculosis. Lancet Infect. Dis., London, v.18, n.3, p.318-327, 2018.

BLAIR, J. M. et al. Molecular mechanisms of antibiotic resistance. Nat. Rev. Microbiol., London, v.13, p. 42-51, 2015.

DE AGUIAR, F. C. et al. Combined effect of conventional antimicrobials with essential oils and their main components against resistant Streptococcus suis strains. Lett. Appl. Microbiol. London, v.68, n.6, p.562-572, 2019.

LIMAVERDE, P. W. et al. Inhibition of the TetK efflux-pump by the essential oil of Chenopodium ambrosioides $L$. and $\alpha$-terpinene against Staphylococcus aureus IS-58. Food. Chem. Toxicol. Sant Lorenç, v. 109, n.2, p.957-966, 2017.

BAKKALI, F. et al. Biological effects of essential oils - a review. Food. Chem. Toxicol. Sant Lorenç, v.46, n.2, p.446-475, 2008.

SWAMY, M. K.; AKHTAR, M. S.; SINNIAH, U. R. Antimicrobial Properties of Plant Essential Oils against Human Pathogens and Their Mode of Action: An Updated Review. Evid. Based Complement. Alternat. Med. London, 2016.

CLINICAL AND LABORATORY STANDARDS INSTUTE (CLSI). Methods for dilution antimicrobial susceptibility tests for bacteria that grow aerobically. 11th edn. Wayne: CLSI, 2018. M7-A6.

HEMAISWARYA, S., KRUTHIVENTI, A. K., DOBLE, M. Synergism between natural products and antibiotics against infectious diseases. Phytomedicine. Amsterdam, v.15, n.8, p.639-652, 2008.

LEWIS, R. E. et al. Comparison of Etest, chequerboard dilution and time-kill studies for the detection of synergy or antagonism between antifungal agents tested against Candida species. J. Antimicrob. Chemother. London, v. 49, n.2, p.345-351, 2002.

RIAHI, L. et al. Phytochemistry, antioxidant and antimicrobial activities of the essential oils of Mentha rotundifolia L. in Tunisia. Ind. Crops Prod., Amsterdam, v. 49, p.883-889, 2013.

ILIĆ, B. S. et al. An in vitro synergistic interaction of combinations of Thymus glabrescens essential oil and its main constituents with chloramphenicol. Sci. World J., London, v.2. 2014.

KANNAPPAN, A. et al. Inhibitory efficacy of geraniol on biofilm formation and development of adaptive resistance in Staphylococcus epidermidis RP62A. J. Med. Microbiol., London, v. 66, v.10, p.1506-1515, 2017.

KOUDORO, Y. A. et al. Phytochemistry, antimicrobial and antiradical activities evaluation of essential oils, ethanolic and hydroethanolic extracts of the leaves of Eucalyptus citriodora hook from Benin. Sci. Study Res. 
Chem Chemic Eng., Bacãu, v.15, n.1, p.59-73, 2014.

TSAI, M. L. et al. Composition and Bioactivity of Essential Oil from Citrus grandis (L.) Osbeck 'Mato Peiyu' Leaf. Molecules. Basileia, v.22, n.12, 2017.

BOSS, R.; OVERESCH, G.; BAUMGARTNER, A. Antimicrobial resistance of Escherichia coli, Enterococci, Pseudomonas aeruginosa, and Staphylococcus aureus from raw fish and seafood imported into Switzerland. J. Food Prot., Des Moines, v.79, n.7, p.1240-1246, 2016.

TAHA, S. M.; ELDAHSHAN, O. A. Chemical Characteristics, Antimicrobial and Cytotoxic Activities of the Essential Oil of Egyptian Cinnamomum glanduliferum Bark. Chem. Biodivers, Zurich, v.14, n.5, 2017.

AHMED, Z. et al. Synergistic effect of Salvadora persica extracts, tetracycline and penicillin against Staphylococcus aureus. Afr. J. Bas. Appl. Sci., [s.I], v.2, n.1-2, p.25-29, 2010.

$A L I, R$. A. et al. Chemical equivalence of different brands of amoxicillin trihydrate and its efficacy against bacterial isolates. PSM Microbiol.,
Narowal, v.1, n.1, p.45-49, 2016.

WANG, J. et al. Characterization of the Adaptive Amoxicillin Resistance of Lactobacillus casei Zhang by Proteomic Analysis. Front Microbiol., Washington, v.9, n.292, 2018.

BASSOLÉ, I. H. N.; JULIANI, H. R. Essential oils in combination and their antimicrobial properties. Molecules, Basileia, v.17, p.3989-4006, 2012.

ROSATO, A. et al. Antibacterial effect of some essential oils administered alone or in combination with norfloxacin. Phytomedicine, Amsterdam, v.14, n.11, p.727-732, 2007.

BRENNAN-KROHN, T.; SMITH, K. P.; KIRBY, J. E. The poisoned well: enhancing the predictive value of antimicrobial susceptibility testing in the era of multidrug resistance. J. Clin. Microbiol., Washington, v.55, n.8, p.2304-2308, 2017.

DOERN, C. D. When does 2 Plus 2 Equal 5 ? A review of antimicrobial synergy testing. J. Clin. Microbiol., Washington, v.52, n.12, p.41244128, 2014.

Submetido em: 25/09/2019

Aceito em: 08/05/2020 